\title{
PENDIDIK DALAM PENGEMBANGAN KURIKULUM
}

\author{
Oleh: \\ Patimah, M.Ag* \\ *Dosen Jurusan PGMI FITK IAIN Syekh Nurjati Cirebon \\ Email:patimah@yahoo.co.id
}

\begin{abstract}
ABSTRAK
Tantangan masa depan yang semakin berat, menuntut output pendidikan yang berkompeten, sehingga diperlukan perubahan dalam konsep belajar. Menurut Menteri Pendidikan dan Kebudayaan, Muhammad Nuh bahwa ditengah perubahan zaman, sistem pendidikan di Indonesia juga harus selalu ikut menyesuaikan. Pengembangan kurikulum 2013 diharapkan dapat menjadi jawaban untuk meningkatkan kemampuan sumber daya manusia untuk menghadapi perubahan dunia. Untuk menghasilkan output pendidikan yang baik diperlukan kesinambungan antara rancangan kurikulum dengan implementasinya. Salah satu sosok yang penting dalam implementasi kurikulum adalah guru. Guru merupakan faktor utama dalam pelaksanaan kurikulum, karena gurulah yang secara langsung berhadapan dengan siswa (subjek kurikulum 2013) dalam proses pembelajaran. Dalam Bahan Uji Publik Kurikulum 2013 disebutkan bahwa kondisi saat ini pendidik dan tenaga kependidikan hanya memenuhi kompetensi profesi dan hanya berfokus pada ukuran kinerja saja, padahal seharusnya seorang pendidik harus memenuhi kompetensi profesi, pedagogi, sosial, dan personal serta memiliki motivasi mengajar. Sehingga kurikulum yang sudah dirancang dapat terlaksana dengan baik.
\end{abstract}

Keyword : Kompetensi, Profesi, Kurikulum 2013

\section{A. PENDAhuluan}

Kurikulum dan pembelajaran merupakan dua hal yang tidak dapat dipisahkan. Sebagai suatu rencana atau program, kurikulum tidak akan bermakna manakala tidak diimplementasikan dalam bentuk pembelajaran. Demikian juga sebaliknya, tanpa kurikulum yang jelas sebagai acuan, maka pembelajaran tidak akan berlangsung secara efektif. Persoalan tentang bagaimana mengembangkan suatu kurikulum, bukanlah hal yang mudah dan tidak sesederhana yang kita bayangkan. Dalam pengembangan kurikulum ada komponen-komponen kurikulum yang harus diperhatikan antara lain komponen tujuan, komponen isi, komponen metode dan komponen evaluasi. 
Dalam pembahasan ini, lebih menitik beratkan pada komponen metode. Dimana komponen metode merupakan komponen yang memiliki peran sangat penting, sebab berhubungan dengan implementasi kurikulum. Metode meliputi rencana, dan perangkat kegiatan yang direncanakan untuk mencapai tujuan tertentu. Upaya untuk mengimplementasikan rencana yang sudah disusun dalam kegiatan nyata agar tujuan yang telah disusun tercapai secara optimal, dinamakan metode.

Kaitannya dengan pembelajaran, ada yang disebut metode pembelajaran. Metode pembelajaran merupakan adalah pola umum rencana interaksi antara siswa dengan guru dan sumber belajar lainnya pada suatu lingkungan belajar untuk mencapai tujuan pendidikan tertentu. Dalam pembelajaran guru memiliki peran penting, karena guru yang berinteraksi langsung dengan peserta didik (subjek kurikulum 2013) sehingga secara tidak langsung kesuksesan untuk mengimplementasikan kurikulum 2013 tergantung pada keterampilan guru. Karena mereka mempunyai andil besar dalam menerapkan kurikulum tersebut.

Pendidikan berintikan interaksi antara pendidik (guru) dan peserta didik (siswa) untuk mencapai tujuan-tujuan pendidikan. Pendidik, peserta didik, dan tujuan pendidikan merupakan komponen utama pendidikan. Ketiganya membentuk suatu triangle, jika hilang salah satu komponen, hilang pulalah hakikat pendidikan. Dalam situasi tertentu tugas guru dapat diwakilkan atau dibantu oleh unsur lain seperti oleh media teknologi, tetapi tidak dapat digantikan. Mendidik adalah pekerjaan professional, oleh karena itu guru sebagai pelaku utama pendidikan merupakan pendidik professional. (Sukmadinata, $2002: 191$ )

Departemen pendidikan dan kebudayaan (1980) telah merumuskan kemampuan-kemampuan yang harus dimiliki guru dan mengelompokkannya atas tiga dimensi umum kemampuan, yaitu; kemampuan professional, kemampuan sosial, dan kemampuan personal (Arif, 2009: 130). Kemampuan professional disini bukan hanya dalam penguasaan materi pelajaran, akan tetapi juga memiliki dan mengetahui strategi, permainan edukasi, ide atau sesuatu yang dapat menciptakan suasana aktif dalam pembelajaran yang bermakna

Adapun kemampuan sosial adalah; guru dapat berkomunikasi secara efektif baik kepada peserta didik, teman-teman guru, kepala sekolah, orang tua murid ataupun 
masyarakat sekitar. Dan yang terakhir adalah kemampuan personal, dimana guru dituntut memiliki sikap dan penampilan yang positif, karena seyogyanya guru adalah model bagi murid-muridnya, maka tidaklah salah jika pepatah mengatakan "guru kencing berdiri, murid kencing berlari".

Berbicara tentang pengembangan kurikulum, penulis akan langsung menjelaskan sedikit tentang definisi tersebut yakni, pengembangan kurikulum adalah perencanaan kesempatan-kesempatan belajar yang dimaksudkan untuk membawa siswa ke arah perubahan-perubahan yang diinginkan dan menilai sampai mana perubahan-perubahan itu telah terjadi pada diri siswa. (Hamalik, 2008 : 97) Jika diteliti lebih jauh, terdapat beberapa kata yang perlu digarisbawahi yakni perencanaan, perubahan, dan menilai yang semua itu berada di bawah tugas seorang guru. Adalah wajar jika guru menempati peran yang cukup penting dalam pengembangan kurikulum, karena seorang guru, dialah orang yang paling mengerti dan mengetahui situasi dan kondisi hasil belajar peserta didiknya serta bertanggung jawab penuh didalamnya. Kegiatan pembelajaran yang dilakukan oleh guru berpangkal pada suatu kurikulum, dan dalam proses pembelajaran guru juga berorientasi pada tujuan kurikulum. Pada sisi lain, guru adalah pembelajar siswa, yang secara kreatif membelajarkan siswa sesuai dengan kurikulum sekolah. Hal itu menunjukkan bahwa dalam tugas pembelajaran dipersyaratkan agar guru memahami kurikulum. (Dimyati, $209: 288)$

Kurikulum memegang peranan penting dalam pendidikan, sebab berkaitan dengan penentuan arah, isi dan proses pendidikan yang pada akhirnya menentukan kualifikasi lulusan suatu lembaga pendidikan. Seiring dengan perkembangan jaman dan tuntutan dari masyarakat, maka dunia pendidikan harus melakukan inovasi dalam pendidikan. Inovasi pendidikan akan berjalan dan mencapai sasarannya jika progam pendidikan tersebut dirancang dan di implementasikan sesuai dengan kondisi dan tuntutan jaman. Sebagai implikasi dari pentingnya inovasi pendidikan menuntut kesadaran tentang peranan guru.

Menurut Undang-undang Nomor 14 Tahun 2005, guru adalah pendidik profesional dengan tugas utama mendidik, mengajar, membimbing, mengarahkan, melatih, menilai, dan mengevaluasi peserta didik pada pendidikan anak usia dini jalur 
pendidikan formal, pendidikan dasar, dan pendidikan menengah. Guru mempunyai kedudukan sebagai tenaga profesional pada jenjang pendidikan dasar, pendidikan menengah, dan pendidikan anak usia dini pada jalur pendidikan formal yang diangkat sesuai dengan peraturan perundang-undangan.

Kedudukan guru dan dosen sebagai tenaga profesional bertujuan untuk melaksanakan sistem pendidikan nasional dan mewujudkan tujuan pendidikan nasional, yaitu berkembangnya potensi peserta didik agar menjadi manusia yang beriman dan bertakwa kepada Tuhan Yang Maha Esa, berakhlak mulia, sehat, berilmu, cakap, kreatif, mandiri, serta menjadi warga negara yang demokratis dan bertanggung jawab. Oleh karena tugas dan kedudukan yang dibebankan pada guru, maka guru wajib memiliki kualifikasi akademik, kompetensi, sertifikat pendidik, sehat jasmani dan rohani, serta memiliki kemampuan untuk mewujudkan tujuan pendidikan nasional. Kompetensi guru meliputi kompetensi pedagogik, kompetensi kepribadian, kompetensi sosial, dan kompetensi profesional yang diperoleh melalui pendidikan profesi.

Menurut Kepala Dinas Pendidikan Pemuda dan Olahraga (Disdikpora) DIY Kadarmanta Baskara Aji, "Kurikulum eksekusinya di tangan guru. Karenanya guru berperan besar dalam implementasinya,". Menurutnya, peran guru dalam mengaplikasikan kurikulum baru memang dibutuhkan saat ini. Sebab kurikulum yang diterapkan pada peserta didik dibuat tidak hanya oleh Kementrian Pendidikan dan Kebudayaan (Kemendikbud) namun juga banyak pihak, termasuk para guru. Maka dari itu, untuk mensukseskan penerapan kurikulum tersebut, guru menjadi faktor yang paling dominan untuk dilaksanakan. Para pendidik itulah yang mengetahui perkembangan ilmu dan perubahan materi kurikulum yang dibutuhkan.

Menurut Murray peran guru dalam kurikulum adalah sebagai berikut: (Sumardi, 2009: 19) Pertama, sebagai implementers, guru berperan untuk mengaplikasikan kurikulum yang sudah ada. Dalam melaksanakan perannya, guru hanya menerima berbagai kebijakan perumus kurikulum. Dalam pengembangan kurikulum guru dianggap sebagai tenaga teknis yang hanya bertanggung jawab dalam mengimplementasikan berbagai ketentuan yang ada. Akibatnya kurikulum bersifat seragam antar daerah yang satu dengan daerah yang lain. Oleh karena itu guru hanya 
sekadar pelaksana kurikulum, maka tingkat kreatifitas dan inovasi guru dalam merekayasa pembelajaran sangat lemah. Guru tidak terpacu untuk melakukan berbagai pembaruan. Mengajar dianggapnya bukan sebagai pekerjaan profesional, tetapi sebagai tugas rutin atau tugas keseharian.

Kedua, peran guru sebagai adapters, lebih dari hanya sebagai pelaksana kurikulum, akan tetapi juga sebagai penyelaras kurikulum dengan karakteristik dan kebutuhan siswa dan kebutuhan daerah. Guru diberi kewenangan untuk menyesuaikan kurikulum yang sudah ada dengan karakteristik sekolah dan kebutuhan lokal. Hal ini sangat tepat dengan kebijakan KTSP dimana para perancang kurikulum hanya menentukan standat isi sebagai standar minimal yang harus dicapai, bagaimana implementasinya, kapan waktu pelaksanaannya, dan hal-hal teknis lainnya seluruhnya ditentukan oleh guru. Dengan demikian, peran guru sebagai adapters lebih luas dibandingkan dengan peran guru sebagai implementers.

Ketiga, peran sebagai pengembang kurikulum, guru memiliki kewenganan dalam mendesain sebuah kurikulum. Guru bukan saja dapat menentukan tujuan dan isi pelajaran yang disampaikan, akan tetapi juga dapat menentukan strategi apa yang harus dikembangkan serta bagaimana mengukur keberhasilannya. Sebagai pengembang kurikulum sepenuhnya guru dapat menyusun kurikulum sesuai dengan karakteristik, visi dan misi sekolah, serta sesuai dengan pengalaman belajar yang dibutuhkan siswa.

Keempat, adalah peran guru sebagai peneliti kurikulum (curriculum researcher). Peran ini dilaksanakan sebagai bagian dari tugas profesional guru yang memiliki tanggung jawab dalam meningkatkan kinerjanya sebagai guru. Dalam melaksanakan perannya sebagai peneliti, guru memiliki tanggung jawab untuk menguji berbagai komponen kurikulum, misalnya menguji bahan-bahan kurikulum, menguji efektifitas program, menguji strategi dan model pembelajaran dan lain sebagainya termasuk mengumpulkan data tentang keberhasilan siswa mencapai target kurikulum. Metode yang digunakan oleh guru dalam meneliti kurikulum adalah PTK dan Lesson Study. 


\section{B. PEMBAHASAN}

\section{Definisi Pendidik}

Dalam pengertian yang sederhana, pendidik adalah orang yang memberikan ilmu pengetahuan kepada anak didik, sedangkan dalam pandangan masyarakat adalah orang yang melaksanakan pendidikan di tempat-tempat tertentu, tidak mesti di lembaga pendidikan formal (Sekolah atau institusi pendidikan dengan kurikulum yang jelas dan terakreditasi), tetapi bisa juga di lembaga pendidikan non formal (Lembaga Pendidikan Ketrampilan, Kursus, di mesjid, di surau/musala, di gereja, di rumah, dan sebagainya).

Undang-undang No. 20 Tahun 2003, Pasal 39 (2) menjelas bahwa pendidik merupakan tenaga profesional yang bertugas merencanakan dan melaksanakan proses pembelajaran, menilai hasil pembelajaran, melakukan pembimbingan dan pelatihan. Sementara itu sebutan pendidik dengan kualifikasi dosen merupakan tenaga profesional yang bertugas merencanakan dan melaksanakan proses pembelajaran, menilai hasil pembelajaran, melakukan pembimbingan dan pelatihan serta melakukan penelitian dan pengabdian kepada masyarakat. Tenaga pendidik meliputi guru, dosen, konselor, pamong belajar, widyaiswara, tutor, instruktur, fasilitator, dan sebutan lain yang sesuai dengan kekhususannya, serta berpartisipasi dalam menyelenggarakan pendidikan. (UU No. 20 tahun 2003 pasal

\section{Definisi Pengembangan Kurikulum}

Pada dasarnya pengembangan kurikulum adalah mengarahkan kurikulum sekarang ke tujuan pendidikan yang diharapkan karena adanya berbagai pengaruh yang sifatnya positif yang datangnya dari luar atau dari dalam diri sendiri dengan harapan agar peserta didik dapat menghadapi masa depannya dengan baik. Definisi lain menjelaskan bahwa pengembangan kurikulum adalah proses perencanaan kurikulum agar menghasilkan rencana kurikulum yang luas dan spesifik. Proses ini berhubungan dengan seleksi dan pengorganisasian berbagai komponen situasi belajar mengajar antara lain penetapan jadwal pengorganisasian kurikulum dan spesifikasi tujuan yang disarankan, mata pelajaran, kegiatan, sumber, dan alat pengukur pengembangan kurikulum yang mengacu pada kreasi sumber unit, 
rencana unit, dan garis pelajaran kurikulum lainnya untuk memudahkan proses belajar mengajar.

Berikut ini adalah beberapa karakteristik dalam pengembangan kurikulum:

1. Rencana kurikulum harus dikembangkan dengan tujuan (goals dan general objectifes) yang jelas.

2. Suatu progam atau kegiatan yang dilaksanakan di sekolah merupakan bagian dari kurikulum yang dirancang selaras dengan prosedur pengembangan kurikulum.

3. Rencana kurikulum yang baik dapat menghasilkan terjadinya proses belajar yang baik karena berdasarkan kebutuhan dan minat siswa.

4. Rencana kurikulum harus mengenalkan dan mendorong difersitas diantara para pelajar.

5. Rencana kurikulum harus menyiapkan semua aspek situasi belajar mengajar, seperti tujuan konten, aktifitas, sumber, alat pengukuran, penjadwalan, dan fasilitas yang menunjang.

6. Rencana kurikulum harus dikembangkan dengan karakteristik siswa pengguna.

7. Rencana kurikulum sebaiknya merefleksikan keseimbangan antara kognitif, afektif, dan psikomotorik.

Beauchamp mengemukakan lima prinsip dalam pengembangan teori kurikulum yaitu, ( Ibrahim, 2006 ) :

1. Setiap teori kurikulum harus dimulai dengn perumusan tentang rangkaian kejadian yang dicakupnya.

2. Setiap teori kurikulum harus mempunyai kejelasan tentang nilai - nilai dan sumber-sumber yang menjadi titik tolaknya.

3. Setiap teori kurikulum perlu menjelaskan karakteristik desain kurikulumnya.

4. Setiap teori kurikulum harus menggambarkan proses-proses penentuan kurikulum serta interaksi diantara proses tersebut.

5. Setiap teori kurikulum hendaknya mempersiapkan ruang untuk dilakukannya proses penyempurnaan. 


\section{Kerangka Pengembangan Kurikulum}

Pengembangan kurikulum harus mengacu pada sebuah kerangka umum, yang berisikan hal - hal yang diperlukan dalam pembuatan keputusan. Ada beberapa hal yang diperlukan dalam pengembangan kurikulum:

Asumsi, Tujuan pengembangan kurikulum, Penilaian kebutuhan, Konten kurikulum, Sumber materi kurikulum, Implementasi kurikulum, Evaluasi kurikulum, Keadaan di masa mendatang. Pesatnya perubahan dalam kehidupan sosial, ekonomi, teknologi, politik serta berbagai peristiwa lainnya memaksa kita semua berfikir dan merespon setiap perubahan yang terjadi. Dalam pengembangan kurikulum, pandangan dan kecenderungan pada kehidupan masa datang sudah menjadi hal yang urgen. Setiap rencana pengembangan kurikulum harus memasukkan pertimbangan kehidupan di masa depan, serta implikasinya Kurikulum memiliki dua sisi yang sama pentingnya yakni kurikulum sebagai dokumen dan kurikulum sebagai implementasinya. Sebagai sebuah dokumen kurikulum berfungsi sebagai pedoman bagi guru dan kurikulum sebagai implementasi adalah realisasi dari pedoman tersebut dalam kegiatan pembelajaran. Guru merupakan salah satu faktor penting dalam implementasi kurikulum.

Dalam Bahan Uji Publik Kurikulum 2013, proses pembelajaran dirancang berpusat pada peserta didik (student centered active learning), tidak lagi berpusat pada guru (teacher centered learning). Selain itu, sifat pembelajaran yang kontekstual artinya, guru tidak hanya beracuan pada buku teks saja tetapi juga harus mampu mengkaikan materi yang disampaikannya secara kontekstual.

Selain itu, rancangan kurikulum 2013 bersifat sentralistik, dimana pemerintah pusat dan daerah memiliki kendali kualitas dalam pelaksanaan kurikulum di tingkat satuan pendidikan. Pemerintah menyiapkan semua komponen kurikulum sampai buku teks dan pedoman, termasuk penyusunan silabus dan RPP.

Karena semua komponen kurikulum sudah diatur oleh pemerintah, maka guru perlu menyesuaikan diri (beradaptasi) agar implementasi kurikulum 2013 dapat terlaksana dengan baik. Menteri Pendidikan dan Kebudayaan Mohammad Nuh menuturkan untuk menghadapi penerapan Kurikulum 2013 ini, guru harus mengikuti pelatihan cara mengajar yang mesti dijalani selama 52 jam. Waktu 
pelatihan 52 jam ini hanya pelatihan awal saja, ke depannya ada model pendampingan dalam pelaksanaan guru mengajar.

Berikut adalah bagan penyiapan dan pembinaan guru dalam rangka implementasi kurikulum 2013.

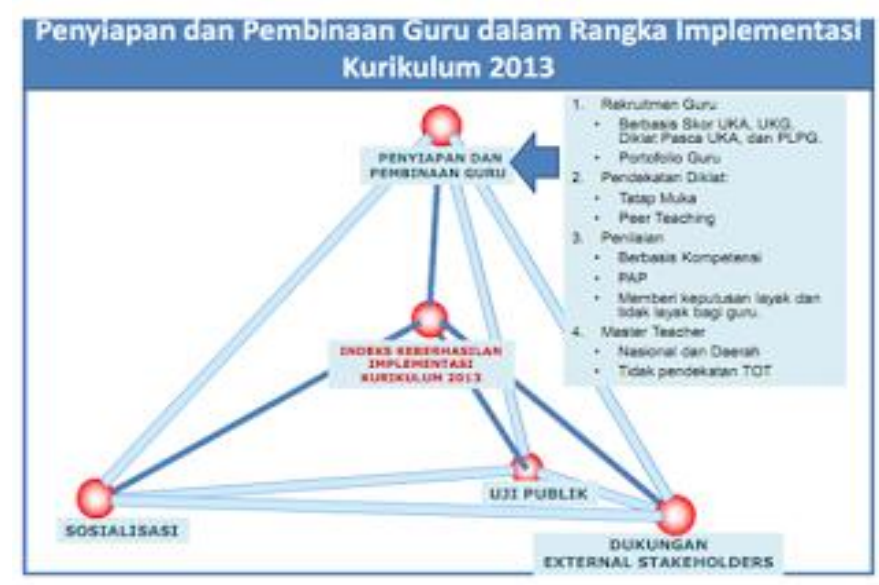

Pelatihan tahap awal ini lebih dititikberatkan pada pelatihan metode pembelajaran Kurikulum 2013 dengan mengedepankan aspek pembelajaran sesuai tujuan kurikulum. Guru diharapkan bisa menjadikan pembelajaran di kelas bukan hal yang membosankan bagi siswa; penyampaian pelajaran yang bukan satu arah; adanya aktivitas peserta didik untuk bisa mengembangkan potensi dirinya; kepahamaan akan ilmu yang dikuasai siswa yang berguna untuk hidup dia kelak; penggunaan sarana dan prasarana dalam melaksanakan pembelajaran; memahami bahwa guru adalah agen perubahan yang membentuk siswa lebih menjadi sosok yang bisa mengembangkan diri tanpa dicekoki oleh sistem hafalan dan target nilai.

Jika melihat pada sejarah pemberlakuan kurikulum sebelumnya, memang secara teoretis kurikulum ini semuanya bertujuan baik. Namun, permasalahan yang kerap terjadi dimana harapan kurikulum dan kenyataan di lapangan seringkali tidak sesuai. Guru memang ujung tombak agen perubahan, namun guru tidak serta merta dapat adaptif terhadap tuntunan perubahan ini. Bagaimanapun harus ada keseriusan dan kesinambungan bahwa guru bukan satu-satunya sosok penanggung jawab sentral akan keberhasilan Kurikulum 2013. Hal ini karena penerapan sistem pendidikan nasional adalah mata rantai dimana dibutuhkan "kerja sama tim" yang padu. Jangan sampai pendidikan akan kembali seperti labirin, dimana apapun 
kurikulumnya, masalahnya itu-itu juga. Sudah waktunya bangsa Indonesia menjadi bangsa yang fokus menggarap pendidikan sebagai sumber peradaban penting bagi terbentuknya insan-insan yang mampu menghadapi tuntutan zaman yang serba cepat ke arah perubahan yang lebih baik.

Jika guru sudah memahami dan mampu mengimplementasikan kurikulum 2013 dengan baik, maka diharapkan akan dihasilkan output pendidikan yang kompeten.

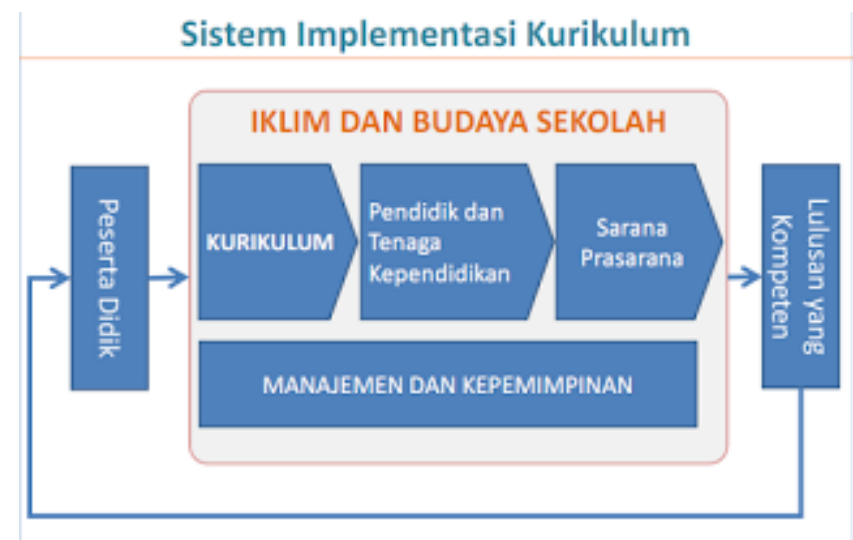

\section{Sumber Daya Manusia Pengembangan Kurikulum}

Sumber Daya Manusia (SDM) pengembangan kurikulum adalah kemampuan terpadu dari daya pikir dan daya fisik yang dimiliki oleh setiap pengembang kurikulum dari tingkat pusat sampai tingkat daerah. Sumber daya manusia tersebut terdiri atas berbagai pakar ilmu pendidikan, administrator pendidikan, guru, ilmuwan, orang tua, siswa, dan tokoh masyarakat.

Unsur ketenagaan tersebut dapat dibagi menjadi dua kategori, yaitu tenaga professional dan tenaga dari masyarakat. Tenaga professional meliputi tenaga kependidikan guru, tenaga kependidikan non-guru dan organisasi professional. Adapun tenaga dari masyarakat meliputi tokoh masyarakat, orang tua, komite sekolah atau dewan sekolah, pihak industry dan bisnis, lembaga sosial masyarakat, instansi pemerintah atau departemen dan non-departemen, serta unsur-unsur masyarakat yang berkepentingan terhadap pendidikan.

Dalam proses pengembangan kurikulum, keterlibatan unsur-unsur ketenagaan tersebut sangat penting, karena keberhasilan suatu system dan tujuan pendidikan merupakan tanggung jawab bersama pada semua tahapan kurikulum. 


\section{Peranan Guru dalam Pengembangan Kurikulum}

Kurikulum memiliki dua sisi yang sama penting, yaitu kurikulum sebagai dokumen dan kurikulum sebagai implementasi. Sebagai sebuah dokumen kurikulum berfungsi sebagai pedoman bagi guru dan kurikulum sebagai implementasi merupakan realisasi dari dokumen dalam bentuk kegiatan pembelajaran di kelas. Keduanya merupakan dua hal yang tak terpisahkan, ada kurikulum berarti ada pembelajaran, dan sebaliknya ada pembelajaran ada kurikulum.

Implementasi kurikulum memerlukan seseorang yang berperan sebagai pelaksananya. Guru merupakan factor penting dalam implementasi kurikulum karena ia merupakan pelaksana kurikulum. Karena itu guru dituntut memiliki kemampuan untuk mengimplemntasikannya, tanpa itu Kurikulum tidak akan bermakna sebagai alat pendidikan, dan sebaliknya pembelajaran tidak akan efektif tanapa kurikulum sebagai pedoman.

Dengan demikian guru menempati posisi kunci dalam implenentasi kurikulum. Selanjutnya dalam proses pengembangan kurikulum peran guru lebih banyak dalam tataran kelas. Murray Print (1993) mengemukakan peran guru dalam tingkatan tersebut sebagai berikut:

\section{Implementer}

Sebagai implementer, guru berperan untuk mengaplikasikan kurikulum yang sudah ada. Di sini guru hanya menerima berbagai kebijakan perumus kurikulum. Guru tidak memiliki kesempatan baik untuk menentukan isi kurikulum maupun menentukan target kurikulum. Peran guru hanya sebatas menjalankan kurikulum yang telah disusun. Peran ini pernah dilaksanakan di Indonesia yaitu sebelum reformasi, yaitu guru sebagai implementator kebijakan kurikulum yang disusun secara terpusat, dituangkan dalam Garis-Garis Besar Program Pengajaran (GBPP). Dalam GBPP yang berbentuk matrik telah ditentukan dari mulai tujuan yang harus dicapai, materi pelajaran yang harus disampaikan, cara yang harus dilakukan, hingga alokasi waktu pelaksanaan. Dalam pengembangan kurikulum guru dianggap sebagai tenaga teknis yang hanya bertanggung jawab dalam mengimplementasikan berbagai ketetntuan 
yang ada. Kurikulum bersifat seragam, sehingga apa yang dilakukan guru di Indonesia bagian timur sama dengan apa yang dilakukan guru di Indonesia bagian barat. Dengan terbatasnya peran guru di sini, maka kreatifitas guru dan inovasi guru dalam merekayasa pembelajaran tidak berkembang. Guru tidak ada motivasi untuk melakukan berbagai pembaruan. Mengajar mereka anggap sebagai tugas rutin dan keseharian, dan bukan sebagai tugas profesional.

\section{Adapter}

Pada peran ini guru memiliki peran lebih dari sekedar pelaksana kurikulum, tetapi sebagai penyelaras kurikulum dengan karakteristik dan dan kebutuhan siswa dan kebutuhan daerah. Guru diberikan kewenangan untuk mnyesuaikan kurikuum dengan kebutuhan daerah ataupun karakteristik sekolah. Dalam Kurikulum Tingkat Satuan Pendidikan (KTSP) yang sekarang dikembangkan di Indonesia, terdapat peran guru dalam fase ini, yaitu bahwa para perancang kurikulum hanya menentukan standar isi sebagai standar minimal yang harus dicapai, bagaimana implementasinya, kapan waktunya, dan hal-hal teknis lainnya ditentukan oeh guru. Dengan demikian peran guru sebagai adapter lebih luas dibandingkan dengan peran sebagai implementer.

\section{Developer}

Dalam tingkat ini guru berperan sebagai pengembang kurikulum, guru memiliki kewenangan dalam mendesain sebuah kurikulum. Guru tidak hanya bisa menentukan tujuan dan isi pelajaran yang akan disampaikan, tetapi bahkan dapat menentukan strategi apa yang harus dikembangkan dan system evaluasi apa yang akan digunakannya. Sebagai pengembang kurikulum guru sepenuhnya dapat menyusun kurikulum sesuai dengan karakteristik, misi dan visi sekolah/madrasah, serta sesuai dengan pengalaman belajar ayang diperlukan anak didik. Dalam KTSP peran ini dapat dilihat dalam pengembangan kurikulum muatan lokal. Dalam pengembangan kurikulum muatan lokal, sepenuhnya diserahkan kepada masing-masing satuan pendidikan, karena itu kurikulum yang berkembang da;at berbeda antara lembaga yang satu dengan lembaga yang lainnya. Kurikulum dikembangkan sesuai dengan karakteristik dan kebutuhan masing-masing satuan pendidikan. 


\section{Researcher}

Fase terakhir adalah peran guru sebagai peneliti kurikulum (curriculum researcher). Peran ini dilaksanakan sebagai bagian dari tugas professional gurub yang memiliki tanggung jawab dalam meningkatkan kinerjanya sebagai guru. Dala mperan ini guru memiliki tanggung jawab untuk menguji berbagai komponen kurikulum, misalnya menguji bahan-bahan kurikulum, menguji efektivitas program, strategi maupun model pembelajaran, termasuk mengumpulkan data tenatang keberhasilan siswa mencapai target kurikulum. Salah satu metode yang dianjurkan dalam penelitian adalah metode Penelitian Tindakan Kelas (PTK), yakni metode peneitian yang berangkat dari masaah ayang dihadapi guru dalam implementasi kurikulum. Melalui PTK, guru berinisiatif melakukan penelitian sekaligus melaksanakan tindakan untuk memecahkan masalah yang dihadapi. Dengan demikian, PTK merupakan salah satu metode yang tidak hanya menambah wawasan guru dan menambah profesionalismenya, tetapi secara terus-menerus dapat meningkatkan kualitas kinerjanya.

\section{SIMPULAN}

1. Kurikulum merupakan bagian dari suatu sistem pengelolaan yang menyangkut perencanaan dan pelaksanaan pembelajaran yang dijadikan pedoman atau panduan bagi guru dalam melaksanakan kegiatan pembelajaran.

2. Peran guru dalam Pengembangan Kurikulum adalah : Sebagai implementer, guru berperan untuk mengaplikasikan kurikulum yang sudah ada. Dalam pengembangan kurikulum guru dianggap sebagai tenaga teknis yang hanya bertanggung jawab dalam mengimplementasikan berbagai ketentuan yang ada. Sebagai penyelaras kurikulum dengan karakteristik dan dan kebutuhan siswa serta kebutuhan daerah. Guru diberikan kewenangan untuk mnyesuaikan kurikuum dengan kebutuhan daerah ataupun karakteristik sekolah. Sebagai pengembang kurikulum, guru memiliki kewenangan dalam mendesain sebuah kurikulum. Guru tidak hanya bisa menentukan tujuan dan isi pelajaran yang akan disampaikan, tetapi bahkan dapat menentukan strategi apa yang harus 
dikembangkan dan system evaluasi apa yang akan digunakannya. Sebagai pengembang kurikulum guru sepenuhnya dapat menyusun kurikulum sesuai dengan karakteristik, misi dan visi sekolah/madrasah, serta sesuai dengan pengalaman belajar yang diperlukan anak didik. Sebagai peneliti kurikulum (curriculum researcher). Peran ini dilaksanakan sebagai bagian dari tugas professional guru yang memiliki tanggung jawab dalam meningkatkan kinerjanya sebagai guru. Dalam peran ini guru memiliki tanggung jawab untuk menguji berbagai komponen kurikulum, misalnya menguji bahan-bahan kurikulum, menguji efektivitas program, strategi maupun model pembelajaran, termasuk mengumpulkan data tentang keberhasilan siswa mencapai target kurikulum.

3. Pengembangan kurikulum pada hakikatnya adalah pengembangan silabus yang didalamnya mencakup komponen-komponen dalam kurikulum yaitu tujuan, metode/alat, materi/bahan ajar dan penilaian. Dilihat dari segi pengelolaannya, pengembangan kurikulum dapat dibedakan antara yang bersifat sentralisasi, desentralisasi, sentral desentral.

4. Karakteristik dalam pengembangan kurikulum:

a) Rencana kurikulum harus dikembangkan dengan tujuan (goals dan general objectifes) yang jelas.

b) Suatu progam atau kegiatan yang dilaksanakan di sekolah merupakan bagian dari kurikulum yang dirancang selaras dengan prosedur pengembangan kurikulum.

c) Rencana kurikulum yang baik dapat menghasilkan terjadinya proses belajar yang baik karena berdasarkan kebutuhan dan minat siswa.

d) Rencana kurikulum harus mengenalkan dan mendorong difersitas diantara para pelajar.

e) Rencana kurikulum harus menyiapkan semua aspek situasi belajar mengajar, seperti tujuan konten, aktifitas, sumber, alat pengukuran, penjadwalan, dan fasilitas yang menunjang.

f) Rencana kurikulum harus dikembangkan dengan karakteristik siswa pengguna. 
g) Rencana kurikulum sebaiknya merefleksikan keseimbangan antara kognitif, afektif, dan psikomotorik.

\section{DAFTAR PUSTAKA}

Dakir. 2004. Perencanaan Dan Pengembangan Kurikulum. Jakarta: Renika Cipta.

Hamalik, Oemar. 2006. Pendidikan Guru Berdasarkan Pendekatan Kompetensi. Jakarta: PT. Bumi Aksara.

Hamalik, Oemar. 2007. Dasar - Dasar Pengembangan Kurikulum. Bandung: PT. Remaja Rosdakarya.

Sukmadinata, Nana Syaodih. 2007. Pengembangan Kurikulum Teori Dan Prakatek. Bandung: PT. Remaja Rosdakarya.

Sanjaya, Wina .2006. Pembelajaran Dalam Implementasi Kurikulum Berbasis Kompetensi. Jakarta: Kencana.

Khaeruddin, Dkk. 2007. Kurikulum Tingkat Satuan Pendidikan (KTSP) Konsep Dan Implementasinya Di Madrasah. Semarang: Pilar Media.

Hamalik, Oemar. 2007. Proses Belajar Mengajar. Jakarta : Bumi Aksara.

" The Central Science". Peran guru dalam pengembangan kurikulum. http://www.chem.yorku.ca/hall_of_fame/whychem.htm. ( Diakses pada tanggal 7 Oktober 2015).

http//:hakekat dan peran guru dalam pengembangan kurikulum.htm ( Diakses pada tanggal 7 Oktober 2015). 